\section{SIMULASI MODEL MATEMATIK DAMPAK PENERAPAN KEBIJAKAN MANDATORI BLENDING BIODIESEL-SOLAR TERHADAP KEBUTUHAN LAHAN PERKEBUNAN KELAPA SAWIT DAN TINGKAT EMISI $\mathrm{CO}_{2}$}

\section{Petir Papilo ${ }^{1}$, Hartrisari H}

E-mail: petirpapilo@uin-suska.ac.id ${ }^{1}$

\section{Penulis}

Petir Papilo adalah dosen program studi Teknik Industri, Fakultas Sains dan Teknologi, UIN SUSKA Riau. Menyelesaikan program Magister pada Departemen Teknik Industri (Industrial Engineering Department) di National University of Malaysia.

Bidang peminatan: Manajemen Kualitas.

\section{Abstract}

The implementation of the mandatory policy of mixing (blending) between biofuels into the fuel has an impact on the icreasing of biodiesel needs, increasing the oil palm plantation area and environmental impact in the form of $\mathrm{CO}_{2}$ emissions by the year 2025. This study aimed to identify the level of each factor needs as well as the impact on the environment. Through the analysis of the design of mathematical models, it is known that the gradually until 2030 has been an increased need for biofuels amounted 14.79 million KL. In an effort to meet the needs of the necessary biofuel oil palm plantations of 35,2 million hectares and an increase in $\mathrm{CO} 2$ emissions of $5,41 \mathrm{Gg} t \mathrm{CO}_{2}$.

\section{Keywords}

Biodiesel, $\mathrm{CO}_{2}$ Emission, Land Area, Mandatory Policy. Biodiesel, $\mathrm{CO}_{2}$ Emission, Land Area, Mandatory Policy.

\section{PENDAHULUAN}

Upaya memaksimalkan pemanfaatan komoditas pertanian dalam negeri guna memenuhi kebutuhan energi nasional terus dilakukan oleh Pemerintah Indonesia. Keseriusan ini ditunjukkan dengan dikeluarkannya Peraturan Menteri ESDM No. 25 Tahun 2013 yang merupakan perubahan atas Peraturan Menteri ESDM No. 32 Tahun 2008, dimana dalam peraturan tersebut terjadi peningkatan prosi pemanfaatan bahan bakar nabati (BBN) dalam pemenuhan energi bahan bakar minyak (BBM) sebesar 10\% pada bahan bakar biodiesel dalam bentuk blending (pencampuran biodiesel dengan solar) atau yang dikenal dengan istilah B10. Upaya ini cukup memberikan hasil positif bagi perekonomian nasional.

Berdasarkan data Direktorat Bioenergi ESDM, tahun 2013 penerapan kebijakan ini, mampu menghemat devisa negara (khususnya dari pemanfaatan biodiesel) sebesar US\$ 831 Juta. Pada tahun 2014, pemerintan kembali merevisi peraturan sebelumnya, dengan mengeluarkan Permen ESDM No. 20 Tahun 2014, dimana porsi pemanfaatan BBN dalam BBM mengalami peningkatan menjadi 
20\% (khusus untuk pemanfaatan biodiesel di bidang transportasi dan industri). Rencana penerapan ini baru akan dilaksanakan pada tahun 2016. Dari penerapan kebijakan ini, secara ekonomis pemerintah mengharapkan akan terjadi penghematan sebesar US\$ 3 Miliar (EBTKE, 2014).

Tabel 1. Penetapan Kewajiban Minimal Pemanfaatan Biodisel (B100)

\begin{tabular}{|l|c|c|c|c|}
\hline \multirow{2}{*}{ Jenis Sektor } & \multicolumn{3}{|c|}{ Permen No. 25 Thn 2013 } & \multirow{2}{*}{ Keterangan } \\
\cline { 2 - 4 } & $\mathbf{2 0 1 5}$ & $\mathbf{2 0 2 0}$ & $\mathbf{2 0 2 5}$ & \\
\hline Transportasi PSO & $10 \%$ & $20 \%$ & $25 \%$ & Terhadap Kebutuhan \\
\hline Transportasi Non PSO & $10 \%$ & $20 \%$ & $25 \%$ & \\
\hline Industri dan Komersial & $10 \%$ & $20 \%$ & $25 \%$ & Terhadap Kebutuhan \\
\hline Pembangkut Listrik & $25 \%$ & $30 \%$ & $30 \%$ & Terhadap Kebutuhan \\
\hline
\end{tabular}

Salah satu komoditas pertanian yang potensial bagi pemenuhan energi adalah hasil perkebunan kelapa sawit. Provinsi Riau merupakan wilayah penghasil kelapa sawit terbesar di Indonesia. Kondisi lahan dan lingkungan yang mendukung, menyebabkan kelapa sawit dapat tumbuh dengan baik di seluruh wilayah kabupaten di Provinsi Riau. Berdasarkan data Dinas Perkebunan Provinsi Riau, hingga tahun 2012, luas wilayah perkebunan kelapa sawit yang ada di Provinsi Riau mencapai 3.423.560 Ha yang terdiri dari perkebunan kelapa sawit milik rakyat dan swasta. Dari total luas tanam yang ada, telah dihasilkan sebanyak 8.128.472,0 ton tandan buah segar kelapa sawit. Artinya dari total luas lahan kelapa sawit nasional, yakni seluas 9.074 .621 ha, 37,7\% diantaranya berada di Provinsi Riau (BPS, 2013).

Beberapa dampak positif pemanfaatan bioenergi terhadap agroindustri kelapa sawit diantaranya telah terjadi peningkatan produksi, konsumsi dan harga minyak kelapa sawit dan harga tandan buah segar kelapa sawit. Disisi lain juga menimbulkan dampak negatif, yakni terjadi peningkatan harga minyak goreng yang berdampak pada produksi dan konsumsi minyak goreng (Joni R, et. al., 2011).

Namun, upaya pengembangan bioenergi melalui pemanfaatan potensi komoditas pertanian, justru menimbulkan permasalahan baru pada aspek kelestarian lingkungan. Dibeberapa negara pengembangan bioenergi merupakan pemicu terjadinya kerusakan lingkungan. Perluasan lahan melalui aktivitas penebangan hutan (deforestation) menimbulkan pengaruh terhadap keanekaragaman hayati (biodiversity), hilangnya kandungan bahan organik di dalam tanah serta peningkatan efek gas rumah kaca yang mengakibatkan meningkatnya suhu permukaan bumi (Gamborg C, et al, 2012).

Potensi bioenergi sangatlah terbatas terutama disebabkan oleh faktor ketersediaan lahan. Lahan dibutuhkan untuk berbagai aspek antara lain untuk keperluan pertanian sebagai upaya pemenuhan kebutuhan pangan, perlindungan hutan dan tempat tinggal penduduk (Popp J et al, 2014).

Kajian ini bertujuan menganalisis dampak yang terjadi akibat dari penerapan kebijakan mandatori pencampuran (blending) antara bahan bakar solar dengan bahan bakar nabati berupa biodiesel kelapa sawit terhadap kebutuhan biodiesel dan kebutuhan lahan perkebunan serta dampaknya terhadap lingkungan dalam hal ini emisi $\mathrm{CO}_{2}$. Analisis kebutuhan lebih difokuskan pada upaya pemenuhan kebutuhan bahan bakar bagi sarana transportasi PSO. Analisis dilakukan melalui perancangan model simulasi matematis yang memperlihatkan hubungan pengaruh antara berbagai faktor diantaranya faktor kebutuhan bahan bakar solar, konsumsi bahan bakar kendaraan, kebijakan mandatori blending B10, B20 dan B25, tingkat produksi CPO dan biodiesel, kebutuhan lahan dan emisi $\mathrm{CO}_{2}$. 


\section{TINJAUAN PUSTAKA}

\section{Konsep Simulasi}

Simulasi adalah suatu teknik numerik untuk kegiatan percobaan pada sebuah komputer digital, yang melibatkan relasi logik dan matematik yang berinteraksi untuk memunculkan perilaku dan struktur dari sistem nyata kompleks sepanjang periode waktu yang dikembangkan (Ravindran et al, 2000). Menurut Eriyatno (2012), simulasi merupakan suatu aktivitas dimana pengkaji dapat menarik kesimpulan-kesimpulan tentang perilaku dari suatu sistem, melalui penelaahan prilaku model yang selaras, dimana hubungan sebab-akibatnya sama dengan atau seperti yang ada pada sistem sebenarnya. Dengan demikian simulasi berkepentingan dengan pembentukan serta pemanfaatan model-model yang secara reslistis mempertanyakan kinerja sistem pada suatu jalur waktu (time path).

Simulasi merupakan suatu pembentukan sebuah model logik matematika dari satu sistem dan menggunakan eksperimen dari model tersebut dengan komputer. Dua langkah dasar dalam simulasi disebutkan dalam definisi berikut ini: (a) pembentukan model, dan (b) eksperimentasi. Pembentukan model melibatkan konstruksi dari sebuah representasi logik matematika suatu sistem dan persiapan program komputer yang menjadikan model tersebut mampu meniru perilaku dari sistem. Ketika sebuah model dari sistem telah valid, fase selanjutnya yang harus dilakukan adalah eksperimentasi dengan model tersebut untuk menentukan bagaimana respon sistem terhadap perubahan pada level-level dari beberapa variabel input.

Simulasi terdiri dari beberapa jenis diantaranya simulasi statik atau dinamik, stokastik atau deterministik, diskret atau kontinu. Simulasi statik adalah simulasi yang tidak berdasarkan pada waktu (waktu tidak memiliki peran di dalamnya). Simulasi ini melibatkan sampel acak untuk membangun outcome statistik. Sementara simulasi dinamik memuat bagian waktu dimana simulasi ini memperlihatkan perubahan status akibat kejadian sepanjang waktu.

Simulasi dengan satu atau lebih dari variabel inputnya adalah acak disebut dengan simulasi stokastik atau probabilistik. Simulasi ini juga menghasilkan nilainilai acak. Sedangkan simulasi dengan tanpa komponen input acak disebut dengan deterministik.

\section{Kajian Literatur}

Pada dasarnya telah banyak peneliti melakukan penelitian berkait dengan penerapan kebijakan dibidang energi dilihat dari dampaknya terhadaplingkungan. Beberapa diantaranya adalah Lathifan (2014); Handoko H (2012); dan Sadewo H (2012).

Lathifan (2014), telah melakukan penelitian berkait dengan perancangan model matematis untuk menganalisis kebijakan pengembangan industri bahan bakar nabati biodiesel berbahan baku kemiri sunan. Penelitian ini menyajikan suatu model matematis untuk menganalisis berbagai alternatif kebijakan pengembangan industri biodiesel kemiri sunan yang dilakukan dalam rangka mencapai target pemerintah dalam pemenuhan prosi BBN sebesar 20\% di tahun 2025. Adapun empat komponen utama dalam sistem yang dianalisis yaitu kebutuhan bahan bakar nabati, kebutuhan lahan kemiri sunan, pembangunan industri pengolahan minyak biodiesel, dan pengaruh kapasitas pabrik yang didirikan terhadap harga biodiesel.

Upaya penerapan kebijakan mandatori blending biodiesel dan solar di Indonesia masih mengalami berbagai kendala di lapangan. Menurut Sadewo $\mathrm{H}$ (2012), faktor utama yang mempengaruhi naik - turunnya permintaan biodiesel di 
Indonesia antara lain adalah implementasi kebijakan, faktor harga bahan bakar, infrastruktur serta tingkat sebaran lokasi produksi biodiesel yang belum merata. Sedangkan faktor yang mempengaruhi penawaran biodiesel di Indonesia adalah faktor harga bahan baku dalam hal ini harga minyak kasar kelapa sawit (crude palm oil), serta harga jual biodiesel yang ada di pasaran dalam negeri.

Handoko H (2012), telah merancang suatu Model Sistem Dinamik dengan nama Model Dinamik Industri Biodiesel Indonesia (MDIBI) yang dikembangkan sebagai platform untuk mengkaji struktur dan perilaku industri biodiesel, diperkaya dengan masukan wawancara dan diskusi dengan panel ahli biodiesel, mensimulasi dampak kebijakan energi, seperti subsidi biodiesel, pengurangan subsidi solar, pajak lingkungan terhadap solar, dan mandat campuran biodieselsolar terhadap kinerja produksi biodiesel, konsumsi biodiesel, tingkat keuntungan industri biodiesel yang ditunjukkan oleh variabel EBITDA dan Pengurangan Emisi Karbon (Carbon Emission Reduction-CER) selama periode simulasi 2005-2030. Berdasarkan MDIBI Skenario 1, ketercapaian kontribusi biodiesel dalam bauran energi Indonesia 2025 untuk menyumbangkan 10,22 juta kilo liter per tahun tidak dapat dicapai dengan struktur dan kondisi saat ini terutama disebabkan tiga faktor utama, yaitu:

1. Mandat campuran yang rendah.

2. Pasokan bahan baku terbatas yang harus dialokasikan untuk industri minyak goreng, oleokimia dan pangan serta biodiesel.

3. Pasar yang masih sangat terbatas pada sektor transportasi public services obligation (PSO) saja.

Target kontribusi biodiesel dalam bauran energi Indonesia 2025 sebesar 10,22 juta ton tersebut dapat dicapai dengan intervensi kebijakan-kebijakan setidaknya pada level Skenario 2, sebagai berikut:

1. Pencabutan subsidi solar ke level harga pasar.

2. Perluasan implementasi kewajiban penggunaan campuran biodiesel ke solar di sektor transportasi non PSO, industri dan pembangkit listrik sehingga mencapai target minimum campuran sebesar $10 \%$ untuk memberikan kepastian pasar.

3. Pengenaan pajak lingkungan terhadap solar sebesar minimum 5\% sebagai tambahan atas pengenaan Pajak Pertambahan Nilai (PPN) dan Pajak Bahan Bakar Kendaraan (PBBKB).

4. Subsidi biodiesel minimum sebesar Rp.2.000/liter.

\section{METODE PENELITIAN \\ Kerangka Pemikiran}

Peningkatan jumlah populasi penduduk secara langsung mempengaruhi permintaan akan kebutuhan bahan bakar. Disisi lain produksi energi fosil yang semakin menipis memaksa pemerintah mencarikan solusi melalui penerapan kebijakan mandatori blending antara BBN dan BBM.

Secara bertahap, kebijakan ini berupaya meningkatkan kontribusi pemanfaatan bahan bakar nabati ke dalam bahan bakar minyak solar, dari tahun 2015 dengan porsi BBN sebesar $10 \%$ hingga mencapai $25 \%$ di tahun 2025. Peningkatan porsi ini menjadi persoalan tersendiri pada sisi produksi biodiesel, perkebunan serta

JIEMS

Journal of Industrial Engineering \&

Management Systems

Vol. 9, No 2, August 2016 


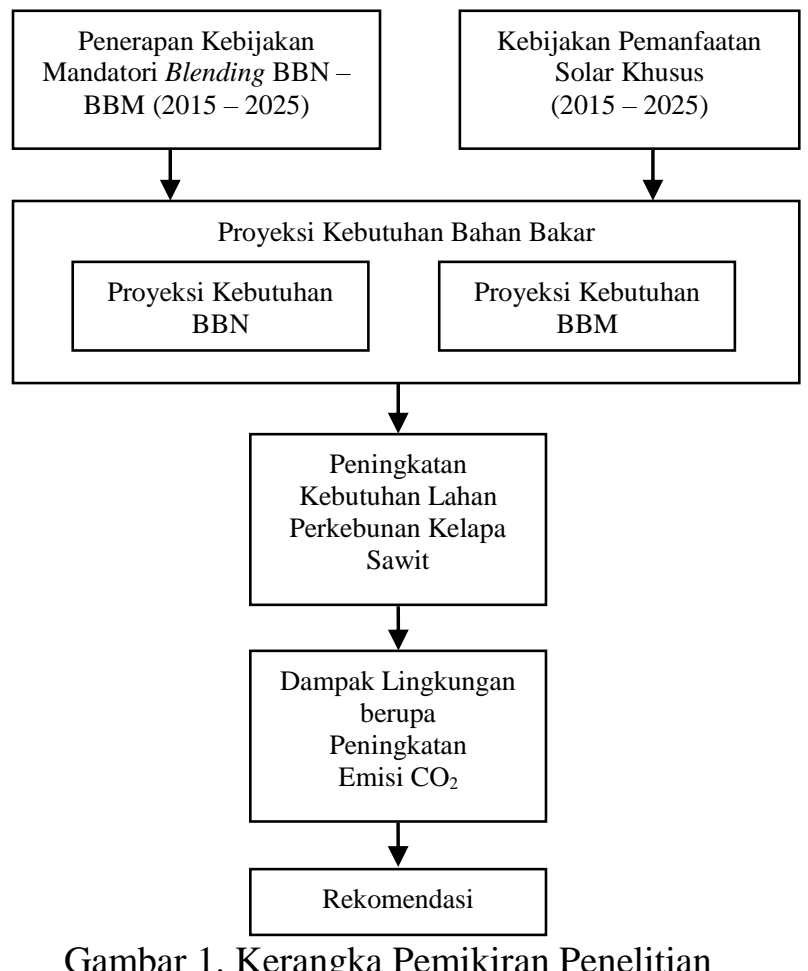

Kajian ini berupaya mengidentifikasi dampak lingkungan yang mungkin terjadi akibat peningkatan kebutuhan lahan kelapa sawit sebagai bahan baku produksi BBN sebagai akibat upaya pemenuhan kebutuhan BBN dalam kebijakan mandatori blending. Melalui perancangan model matematis akan diketahui beberapa parameter penting diantaranya, tingkat kebutuhan bahan bakar solar pada sektor transprotasi PSO, kebutuhan bahan bakar nabati berupa biodiesel menurut peningkatan jumlah kendaraan berbahan baku solar, kebutuhan luas lahan perkebunan kelapa sawit serta dampak lingkungan berupa emisi $\mathrm{CO}_{2}$ akibat proses pembebasan lahan jika melalui praktek pembakaran.

Hasil perhitungan ini menjadi dasar dalam pengajuan rekomendasi dalam penyusunan dan penerapan kebijakan dimasa mendatang, terutama dalam kaitannya dengan dampak lingkungan.

\section{Data Penelitian}

Dalam penelitian ini, data yang diperlukan antara lain adalah data tingat konsumsi solar pertahun dan data produktivitas lahan perkebunan kelapa sawit, rendemen serta massa jenis minyak sawi. Data pada umumnya berupa data sekunder yang diperoleh dari laporan statistik serta kajian literatur terkait.

\section{Tahapan Penelitian}

Adapun tahapan penelitian dapat digambarkan melalui diagram sebagai berikut:

\section{JIEMS}

Journal of Industrial Engineering \&

Management Systems

Vol. 9, No 2, August 2016 


\section{JIEMS}

Journal of Industrial Engineering \& Management Systems Vol. 9, No 2, August 2016

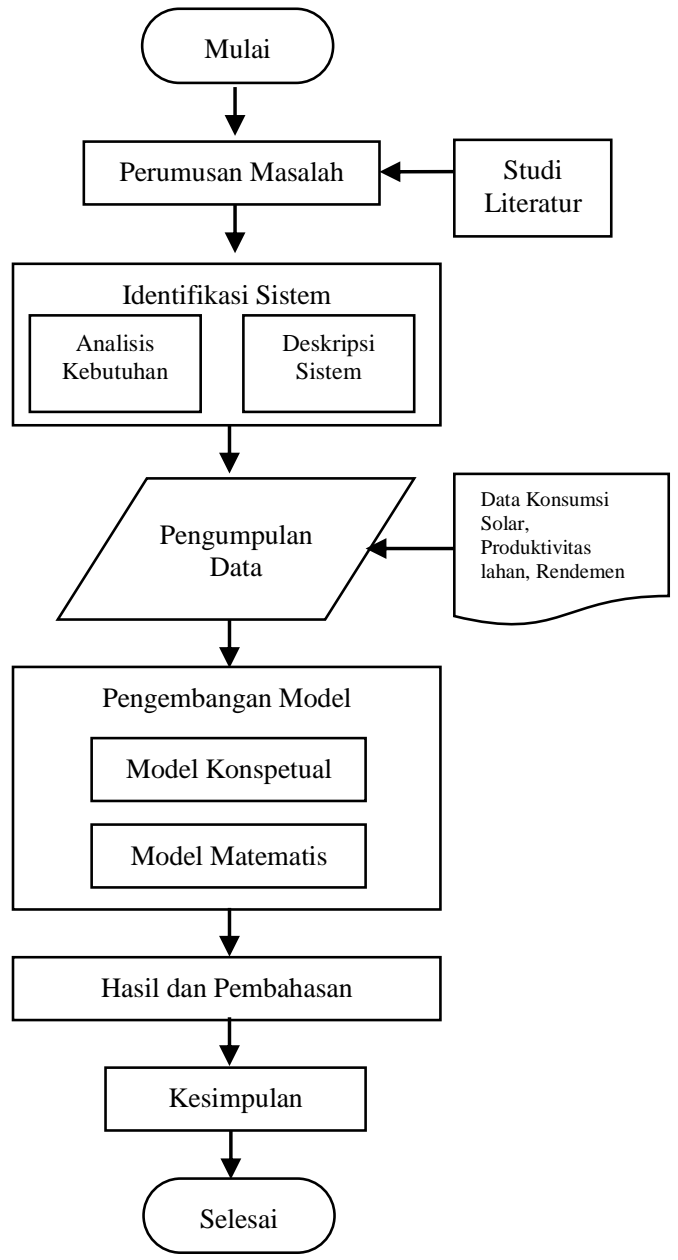

Gambar 2. Tahapan Penelitian

Tahapan penelitian ini antara lain adalah:

1. Perumusan masalah kajian

2. Studi literatur terhadap beberapa kajian terkait.

3. Identifikasi Sistem

4. Identifikasi sistem meliputi penentuan sistem yang diteliti, aktor dan analisis kebutuhan, boundary system, dan penentuan faktor-faktor yang mempengaruhi output.

5. Pengumpulan Data

6. Berupa data sekunder yang diperoleh dari sumber laporan statistik maupun dari kajian-kajian terdahulu.

7. Pengembangan Model

8. Perancangan model dalam bentuk model konseptual yang hubungan antar komponen digambarkan melalui influence diagram kemudian dilakukan penyusunan model matematika.

9. Analisis dan Pembahasan

10. Model matematis yang telah dirancang di gunakan untuk memproyeksi kebutuhan BBN, kebutuhan lahan dan tingkat emisi CO2. Analisis dilakukan dengan menggunakan program Ms Excel.

11. Rekomendasi

12. Berdasarkan hasil analisis akan diberikan rekomendasi berupa masukan masukan sebagai antisipasi atas dampak yang ditimbulkan dari penerapan kebijakan mandatori terhadap lingkungan 


\section{HASIL PENELITIAN DAN PEMBAHASAN Analisis Kebutuhan}

Pelaku utama pengelolaan bahan bakar di Indonesia adalah pemerintah dalam hal ini Kementrian Energi dan Sumber Daya Mineral (KESDM). Sedangkan pengelolaan komersialisasi bahan bakar sepenuhnya diserahkan kepada Badan Usaha Milik Negara (BUMN) dalam hal ini PT. Pertamina. Perancangan kebijakan seperti halnya kebijakan mandatori blending BBM - BBN sepenuhnya dilakukan di tingkat pemerintahan bersama dengan dewan legislatif DPR. Sementara pelaksanaan praktek blending mekanismenya diserahkan kepada PT. Pertamina.

Kebutuhan utama dari penerapan kebijakan mandatori blending BBM - BBN bagi pemerintah adalah terwujudnya ketahanan energi dalam jangka panjang melalui pemanfaatan bahan bakar nabati. Kebijakan ini sekaligus berupaya menjaga keseimbangan antara kebutuhan energi dan pangan.

Disisi lain, PT Pertamina berharap penerapan ini benar-benar dapat diterapkan di masyarakat sebagai upaya peningkatan profit dari penjualan bahan bakar khusus pengganti solar yang merupakan hasil pencampuran antara BBN - BBM, atau yang biasa disebut biosolar.

\section{Deskripsi Sistem}

Sistem ini menggambarkan hubungan pengaruh antara penerapan kebijakan mandatori BBN - BBM terhadap kebutuhan biodiesel, kebutuhan lahan serta dampak peningkatan emisi $\mathrm{CO}_{2}$. Beberapa atribut penting dalam menentukan pengaruh diantaranya adalah peningkatan jumlah penduduk, peningkatan jumlah kendaraan, kebutuhan BBM Solar, kebutuhan BBN biodiesel, kebutuhan lahan kelapa sawit serta tingkat emisi $\mathrm{CO} 2$.

Sistem ini pada hakekatnya menggambarkan hubungan supply - demand dari target pemenuhan kebutuhan energi nasional dalam periode rentang waktu yang panjang. Dengan menggunakan data historis, model dirancang untuk melihat trend peningkatan kebutuhan biodiesel, kebutuhan luas lahan serta peningkatan dampak lingkungan. Gambaran sistem dapat diilustrasikan dalam bentuk Rich Picture pada Gambar 3.

\section{Perancangan Model Konseptual}

Model konseptual adalah model yang dibangun untuk menggambarkan kondisi permasalahan dan sistem eksisting pada objek amatan. Perancangan model bertujuan untuk menggambarkan hubungan antara aspek sistem (input, output, dan komponen sistem) yang dituangkan kedalam influence diagram. Model konseptual yang terbentuk akan diformulasikan ke dalam bentuk model matematis.

\section{JIEMS}

Journal of Industrial Engineering \&

Management Systems

Vol. 9, No 2, August 2016 


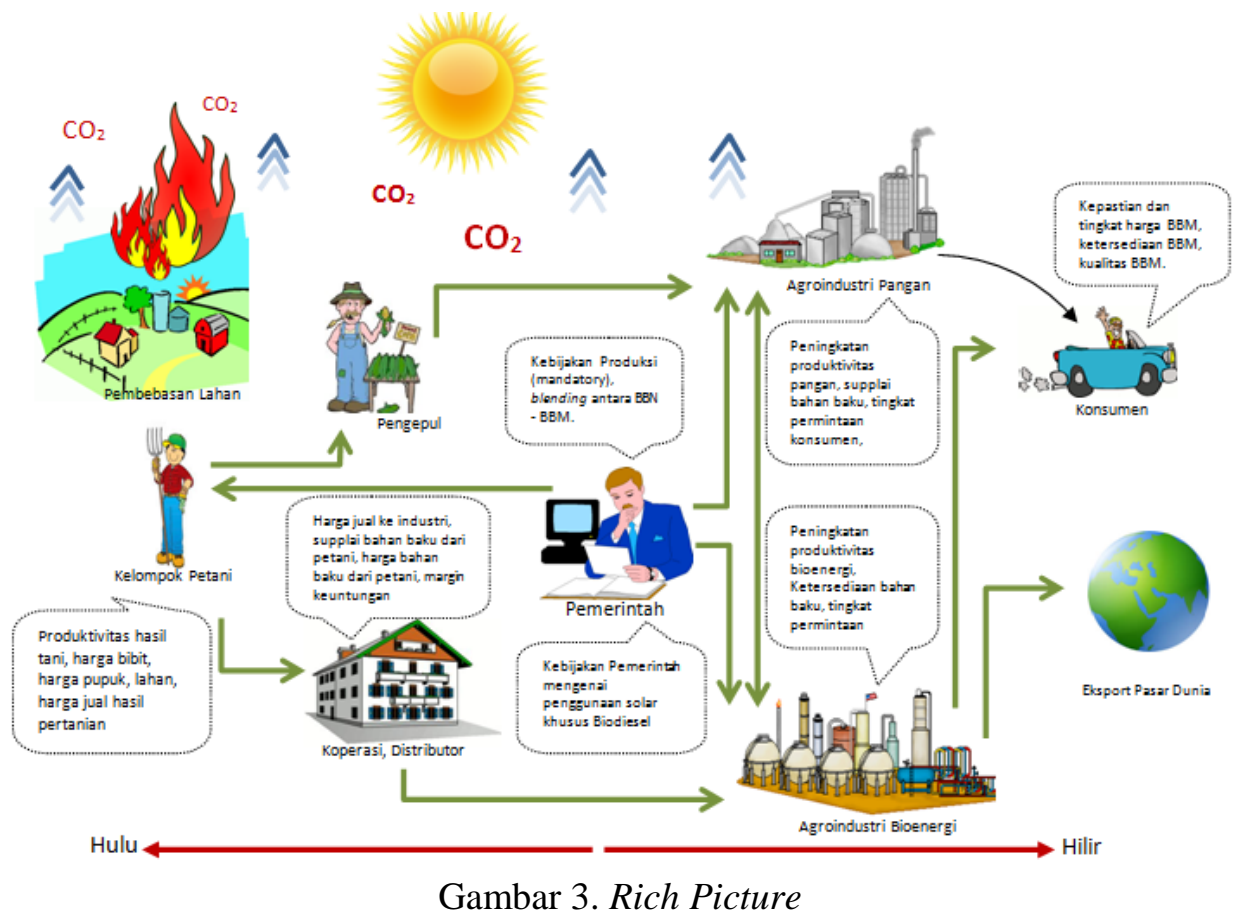

Perancangan model matematika dibagi menjadi dua bagian, yaitu model sistem secara statis dan model sistem secara dinamis. Model secara statis menjelaskan satu tahapan perkembangan dalam satu tahun, sedangkan model secara dinamis menjelaskan beberapa tahapan perkembangan dalam rentang waktu yang telah ditentukan.

Penerapan mandatori blending khususnya untuk kebutuhan transportasi PSO, dilakukan dalam tiga rentang waktu yakni:

1. Dari tahun 2015 - 2020 dengan porsi biodiesel dalam solar sebesar $10 \%$,

2. Dari tahun 2020 - 2025 dengan porsi biodiesel dalam solar sebesar $20 \%$

3. Dari tahun 2025 - 2030 dengan porsi biodiesel dalam solar sebesar $25 \%$.

Jadi dengan kata lain bahwa, dalam analisis proyeksi ini, kebutuhan biodiesel, kebutuhan lahan dan dampak emisi $\mathrm{CO} 2$, diukur dalam rentang waktu dari tahun $2015-2030$.

\section{Perancangan Model Matematis}

\section{Model Pengukuran Kebutuhan BBN(Biodiesel)}

Menurut Rinilaili dan Yuliwati (2009), laju konsumsi BBM nasional sekitar 6$7 \%$ pertahun. Namun dalam kajian ini, pengukuran kebutuhan biodiesel dilakukan melalui perancangan model matematis. Adapun persamaan matematis dalam menentukan proyeksi kebutuhan biodiesel $(B n)$

$B n=S c \times M b p \times U s p$

\section{JIEMS}

Dimana:

Sc $\quad$ : Konsumsi Solar (KL)

Mbp : Persentase Campuran Biodiesel (\%)

Usp : Persentase Penggunaan Solar Khusus (\%)

Journal of Industrial Engineering \&

Management Systems

Vol. 9, No 2, August 2016 


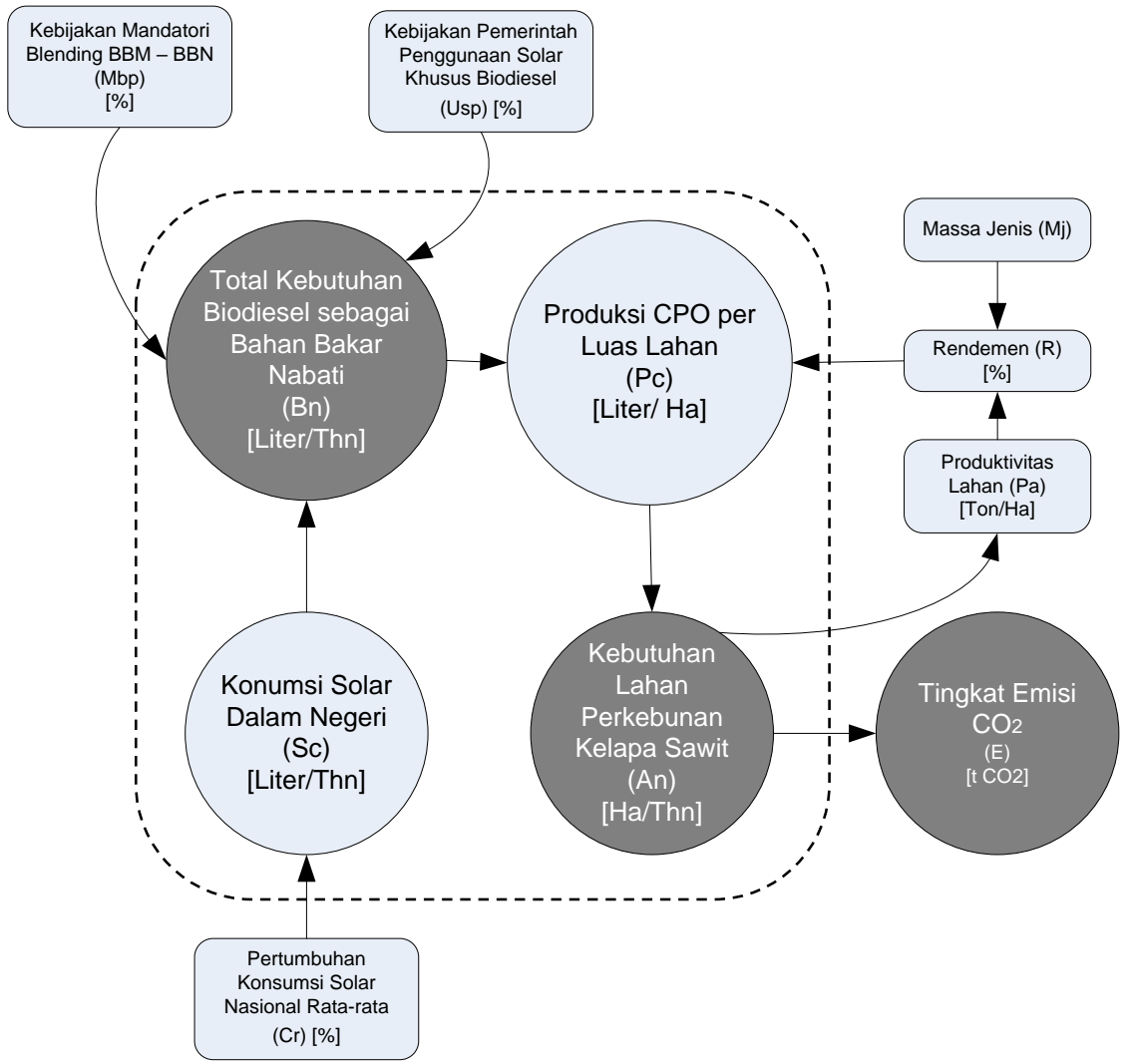

Gambar 4. Influence Diagram Kebutuhan Biodiesel, Kebutuhan Lahan dan Tingkat Emisi $\mathrm{CO}_{2}$

Sesuai dengan kebijakan mandatori, secara berangsung-angsur mulai tahun 2015 hingga tahun 2025 pencampuran biodiesel ke solar secara berturut mulai dari 10\%, 20\% hingga 25\%. Dengan demikian maka nilai Mbp akan berfluktuasi dari $10 \%$ hingga $25 \%$. Sementara kebijakan penggunaan solar dalam negeri telah ditetapkan sebesar $70 \%$. persamaan:

Kebutuhan jumlah solar setiap tahunnya dapat dihitung dengan

$S c=\left(\overline{C r} \times S c_{t-1}\right)+S c_{o}$

Dimana:

$\overline{\mathrm{Cr}} \quad$ : Rata-rata Pertumbuhan Konsumsi Solar (\%)

$S c_{o} \quad$ : Konsumsi Solar pada tahun awal (KL)

\section{Model Pengukuran Kebutuhan Lahan menurut Penerapan Mandatori Blending}

Kebutuhan luas lahan perkebunan kelapa sawit ditentukan berdasarkan kebutuhan biodiesel per tahun berbanding tingkat produksi minyak kelapas sawit (CPO) per luas lahannya. Tingkat produksi CPO dipengaruhi pula oleh beberapa faktor diantaranya tingkat produktivitas perkebunan kelapa sawit, rendemen, serta massa jenis minyak kelapa sawit. Adapun model matematis penentuan kebutuhan luas lahan $(A n)$ perkebunan kelapa sawit adalah sebagai berikut :

$$
A n=B n / P c
$$


Dimana:

Bn : Kebutuhan Biodiesel (KL)

$P c \quad$ : Produksi Biodiesel (KL/Ha)

Sementara produksi biodiesel dapat dihitung dengan persamaan:

$P c=P a \times R \times M j$

Dimana:

$\mathrm{Pa} \quad$ : Produktivitas lahan (Ton/ $\mathrm{Ha}$ )

$R \quad:$ Rendemen (\%)

Mj $\quad$ : Massa Jenis Minyak Kelapa Sawit

Pada umumnya rendemen minyak dari tandan buah segar kelapa sawit adalah $20 \%$, sementara nilai rendemen adalah sebesar 0,89 .

\section{Model Matematis Pengukuran Emisi $\mathrm{CO}_{2}$ dari Lahan Perkebunan Kelapa Sawit}

Emisi Gas Rumah Kaca (glass house gas - GHG) pada perkebunan kelapa sawit, cenderung dikeranakan adanya praktek perluasan lahan untuk meningkatkan produktivitas hasil suatu perkebunan kelapa sawit. Untuk mengukur emisi yang terjadi pada suatu lahan perkebunan, dapat dilakukan dengan persamaan sebagai berikut (2012):

$E\left(\right.$ Emisi $\left.\mathrm{CO}_{2}\right)=(E a+E b b+E b o-S a) / \Delta t$

Dimana:

1. Ea adalah emisi akibat terbakarnya jaringan di permukaan tanah lahan.

Ea $=$ C tanaman yang terbakar $x 3,67$.

Dimana, angka 3,67 adalah faktor konversi dari $\mathrm{C} \mathrm{ke} \mathrm{CO}_{2}$. Berat atom $\mathrm{C}=12$, berat atom $\mathrm{O}=16$, maka $\mathrm{CO}_{2} / \mathrm{C}=(12+(16 \times 2) / 12$ atau 44/12 $=3,67$. Jika hutan gambut memiliki kandungan $\mathrm{C}$ tanaman sebanyak $100 \mathrm{t} / \mathrm{ha}$, maka: $\mathrm{Ea}=100 \mathrm{t}$ $\mathrm{C} / \mathrm{ha} * 3,67 \mathrm{CO}_{2} / \mathrm{C}=367 \mathrm{t} \mathrm{CO}_{2} /$ ha.

2. Ebb merupakan emisi dikarenakan kebakaran lahan gambut.

$E b b=\operatorname{VGT} \times C d \times 3,67 \mathrm{CO}_{2} / C$.

Dimana:

VGT = Volume Gambut Terbakar $\left(\mathrm{m}^{3}\right)$

$\mathrm{Cd}=$ Kerapatan Carbon $\left(\mathrm{t} \mathrm{C} / \mathrm{m}^{3}\right)$

Misalnya: Jika 6.000 ha gambut terbakar dengan kedalaman rata-rata $12 \mathrm{~cm}$, maka: Volume gambut terbakar $=0,12 \mathrm{~m} * 60.000 .000 \mathrm{~m}^{2}=7.200 .000 \mathrm{~m}^{3}$.

Sementara:

$C d=D b \times C$

Dimana:

$\mathrm{Cd}=$ Kerapatan Cardon $\left(\mathrm{t} / \mathrm{m}^{3}\right)$

$\mathrm{Db}=$ Bulk density atau bobot isi gambut;

$\mathrm{C}=\% \mathrm{C}$ organik.

Jika Cd = 0,04 t/m $/ \mathrm{m}^{3}$, maka: $\mathrm{Ebb}=7.200 .000 \mathrm{~m}^{3} * 0,04 \mathrm{t} \mathrm{C} / \mathrm{m}^{3} * 3,67 \mathrm{CO}_{2} / \mathrm{C}=$ 1.056.960 t $\mathrm{CO}_{2}$
Journal of Industrial Engineering \& Management Systems Vol. 9, No 2, August 2016 
3. Ebo merupakan Emisi dari dekomposisi gambut. Pendugaan untuk mengukur emisi dari dekomposisi gambut dapat dilakukan berdasarkan penurunan permukaan gambut (subsiden). Subsiden berlangsung sangat cepat beberapa tahun pertama sesudah gambut didrainase dan kemudian akan mencapai kestabilan sekitar $2 \mathrm{~cm} /$ th. Dijelaskan lebih jauh bahwa dengan asumsi tidak terjadi kebakaran, maka dekomposisi gambut menyumbang 60\% terhadap subsiden sedangkan pemadatan (konsolidasi) menyumbang $40 \%$.

$E b o=S b(m) \times C d\left(t C / m^{3}\right) \times C\left(t \mathrm{CO}_{2} / C\right) \times L\left(m^{2}\right)$

Berdasarkan prinsip tersebut, apabila dalam 25 tahun gambut mengalami subsiden $(S b)$ setinggi $100 \mathrm{~cm}$ maka $60 \% * 100 \mathrm{~cm}=60 \mathrm{~cm}$ dari subsiden tersebut disebabkan oleh dekomposisi gambut. Jika kerapatan karbon $\mathrm{Cd}=0,04$ $\mathrm{t} / \mathrm{m}^{3}$ maka dari $\mathrm{L}=6.000$ ha lahan emisi yang terjadi:

Ebo $=0,60 \mathrm{~m} * 0,04 \mathrm{t} \mathrm{C} / \mathrm{m}^{3} * 3,67 \mathrm{t} \mathrm{CO}_{2} / \mathrm{C} * 6.000 \mathrm{ha} * 10.000 \mathrm{~m}^{2} / \mathrm{ha}=$ $5.284 .800 \mathrm{t} \mathrm{CO}_{2}$

4. $S a$ adalah Sekuestrasi atau penambahan karbon oleh tanaman. Sa merupakan rata-rata waktu simpan kandungan karbon pada jaringan tanaman $(\mathrm{t} / \mathrm{ha}) * 3,67$. Misalnya, jika pertambahan kandungan karbon rata-rata waktu dari satu siklus ekonomi kelapa sawit 25 tahun $=40 \mathrm{t} \mathrm{C} / \mathrm{ha}$, maka untuk 6.000 ha lahan, sumbangannya dalam mengurangi $\mathrm{CO}_{2}$ di atmosfir $=40 \mathrm{t} \mathrm{C} / \mathrm{ha} * 6.000$ ha $*$ $3,67 \mathrm{t} \mathrm{CO}_{2} / \mathrm{C}=880.000 \mathrm{t} \mathrm{CO}_{2}$.

$S a=S x C$

Dimana:

$\mathrm{S}$ = rata-rata waktu simpan kandungan karbon pada jaringan tanaman (t/ha). Misalnya, jika pertambahan kandungan karbon rata-rata waktu dari satu siklus ekonomi kelapa sawit 25 tahun $=40 \mathrm{t} \mathrm{C} / \mathrm{ha}$, maka untuk 6.000 ha lahan, sumbangannya dalam mengurangi $\mathrm{CO}_{2}$ di atmosfir $=40 \mathrm{t} \mathrm{C/ha} * 6.000$ ha $*$ $3,67 \mathrm{t} \mathrm{CO}_{2} / \mathrm{C}=880.000 \mathrm{t} \mathrm{CO}_{2}$.

5. $\Delta \mathrm{t}=$ Perbedaan atau lamanya waktu yang diperhitungkan. Penetapan lamanya waktu tergantung keperluan; bisa dalam hitungan menit, jam, sampai tahunan.

\section{Validasi dan Verifikasi Model}

\section{Proyeksi Kebutuhan Biodiesel menurut Konsumsi Solar}

Kebutuhan biodiesel ditentukan berdasarkan konsumsi BBM jenis solar yang diproyeksinya berdasarkan data historis dari tahun 2015 hingga tahun 2030. Selain itu, penentuan jumlah kebutuhan biodiesel juga dipengaruhi oleh besarnya persentase pencampuran antara BBM solar dengan BBN yang dilakukan secara incremental hingga tahun 2030. Konsumsi BBM solar di perkirakan terus mengalami peningkatan sebesar 6-7\% (2009). Adapun proyeksi kebutuhan biodiesel dari tahun 2015-2030 dapat disajikan pada grafik 2.

Melalui grafik dapat dilihat bahwa kebutuhan biodiesel mengalami peningkatan secara incremental seiring dengan penerapan kebijakan mandatori. Adapun kebutuhan biodiesel dari tahun 2015 hingga tahun 2030 bergerak diantara

\section{JIEMS}

Journal of Industrial Engineering \& Management Systems Vol. 9, No 2, August 2016
2.301.746 KL hingga 14.799. 309 KL.

Sementara itu, porsi pemenuhan masing-masing target blending antara konsumsi solar dengan kebutuhan biodiesel dari tahun 2015 hingga tahun 2030 dapat disajikan melalui tabel 2. 


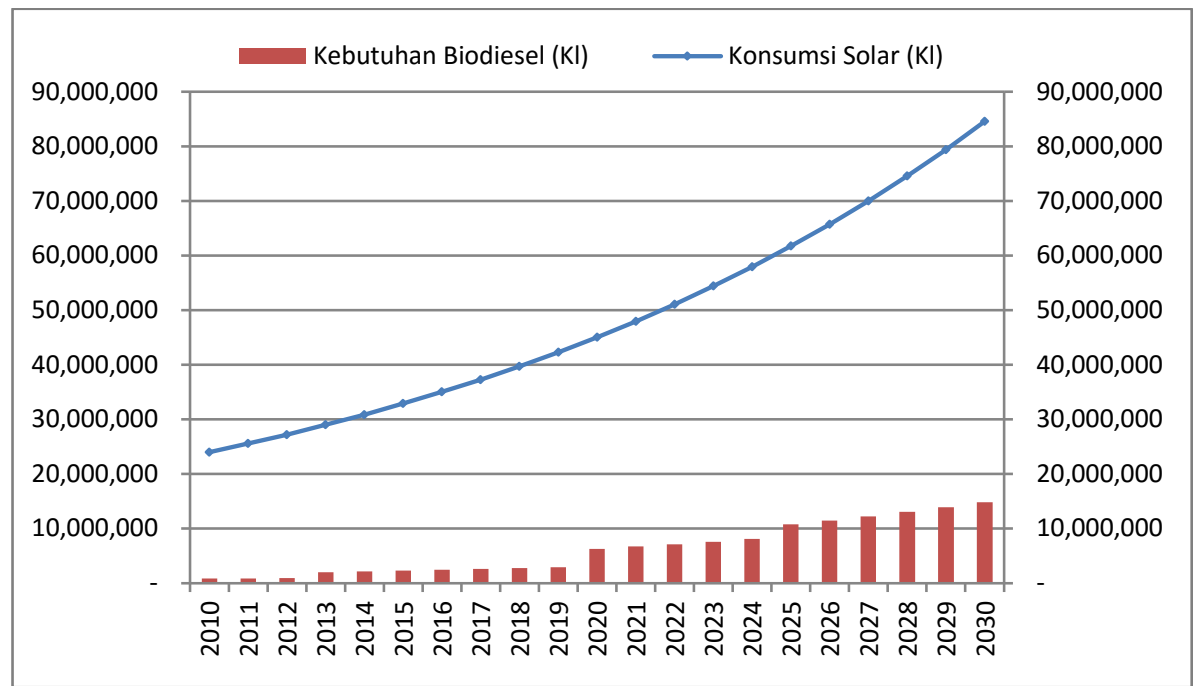

Gambar 5. Proyeksi Kebutuhan Biodiesel

Tabel 2. Perbandingan Porsi Kebutuhan Biodiesel dan Solar pada Blending B10, B20 dan B25

\begin{tabular}{|c|c|c|c|c|}
\hline Jenis Pencampuran & Biodiesel (KL) & $\%$ & $\begin{array}{c}\text { Solar } \\
(\mathrm{KL})\end{array}$ & $\%$ \\
\hline B10 & 13.105 .313 & $10,5 \%$ & 187.218 .758 & $21,28 \%$ \\
\hline B20 & 35.910 .829 & $28,7 \%$ & 256.505 .923 & $29,16 \%$ \\
\hline B25 & 76.300 .494 & $60,9 \%$ & 436.002 .826 & $49,56 \%$ \\
\hline & 125.316 .637 & & 879.727 .506 & \\
\hline
\end{tabular}

Grafik perbandingan bidiesel dan solar menurut penerapan kebijakan mandatori B10, B20 dan B25 dapat disajikan sebagai berikut:

\section{JIEMS}

Journal of Industrial Engineering \&

Management Systems

Vol. 9, No 2, August 2016

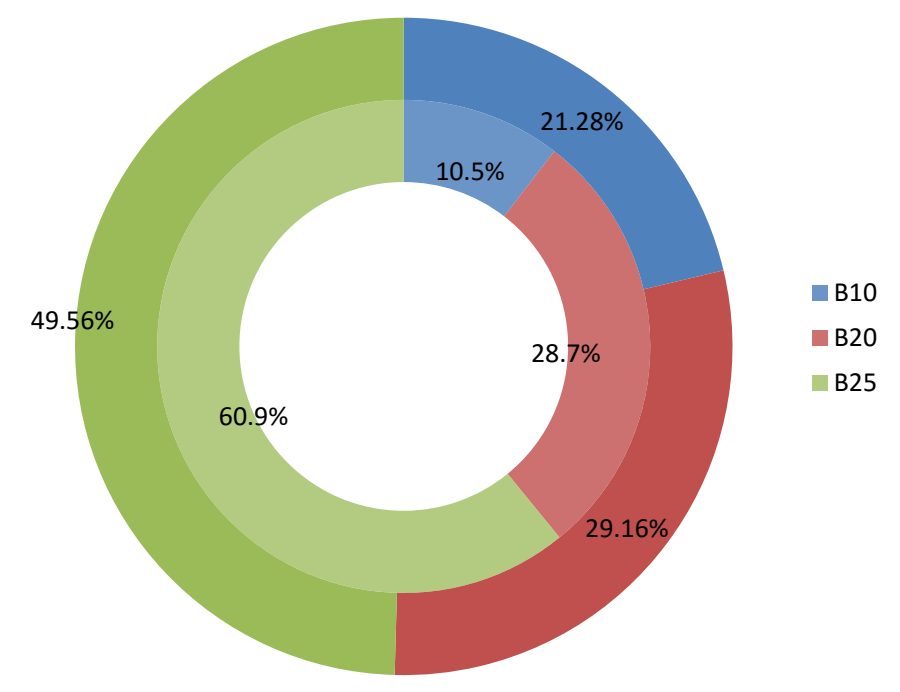

Gambar 6. Porsi Kebutuhan Biodiesel Menurut Konsumsi Solar pada Penerapan Mandatori Blending 


\section{Proyeksi Kebutuhan Lahan Menurut Kebutuhan Konsumsi Biodiesel}

Dalam menentukan kebutuhan luas lahan perkebunan kelapa sawit, perlu ditetapkan beberapa asumsi sebagai berikut:

- Perkebunan mampu menghasilkan 20 - 25 ton TBS per luas 1 ha.

- Rendemen Pabrik Kelapa Sawit $=20 \%$.

- Massa jenis CPO = 0,89 ton/KL.

Berdasarkan kebutuhan biodiesel selama tahun 2015 hingga tahun 2030, maka dapat diproyeksikan kebutuhan luas lahan perkebunan kelapa sawit sebagai berikut:

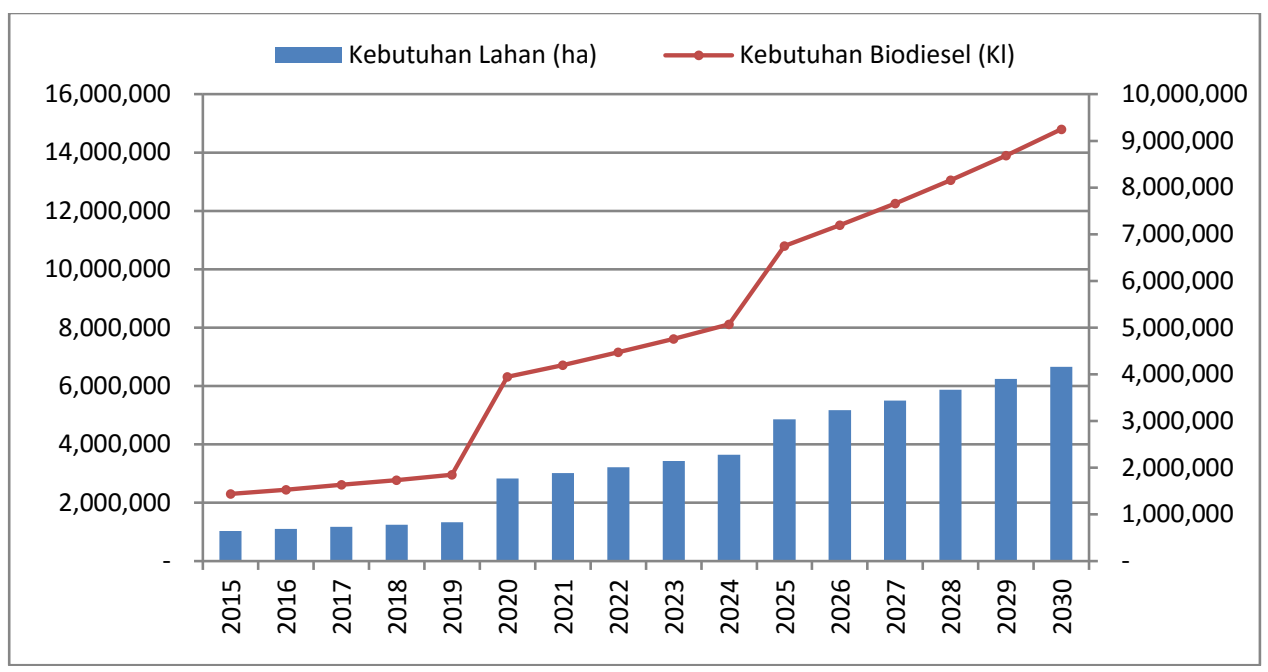

Gambar. 5. Proyeksi Kebutuhan Luas Lahan Perkebunan Kelapa Sawit Menurut Kebutuhan Biodiesel

Melalui grafik di atas terlihat bahwa kebutuhan lahan perkebunan cenderung mengalami peningkatan setiap tahunnya, mulai dari tahun 2015 hingga tahun 2030. Berdasarkan data yang ada, untuk memenuhi kebutuhan BBN biodiesel di tahun 2015 dibutuhkan lahan seluas $646.558 \mathrm{Ha}$. Sedangkan untuk memenuhi kebutuhan di tahun 2030, dibutuhkan areal perkebunan kelapa sawit seluas 4.157.109 Ha. Sehingga total kebutuhan lahan hingga tahun 2030 adalah 35.201.302 Ha.

\section{Emisi CO2 akibat Perlausan Lahan}

Dalam menentukan besaran emisi $\mathrm{CO}_{2}$ yang ditimbulkan, digunakan beberapa parameter asumsi sebagai berikut:

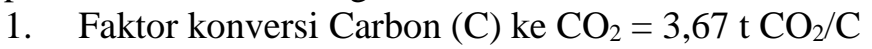

2. Kandungan Carbon tanaman $=100 \mathrm{t} / \mathrm{ha}$

3. Kedalaman rata-rata gambut terbakar $=12 \mathrm{~cm}$

4. Kerapatan Carbon $(\mathrm{Cd})=0,04 \mathrm{t} / \mathrm{m}^{3}$

5. Penurunan permukaan gambut (subsiden) $=60 \mathrm{~m}$

6. Pertambahan $\mathrm{C}$ dari tanaman baru/ tahun $=1,6 \mathrm{t} \mathrm{C} / \mathrm{ha}$.

Adapun hasil analisis pengukuran proyeksi emisi $\mathrm{CO} 2$ dari lahan perkebunan

\section{JIEMS}

Journal of Industrial Engineering \& Management Systems Vol. 9, No 2, August 2016

kelapa sawit adalah sebagai berikut 


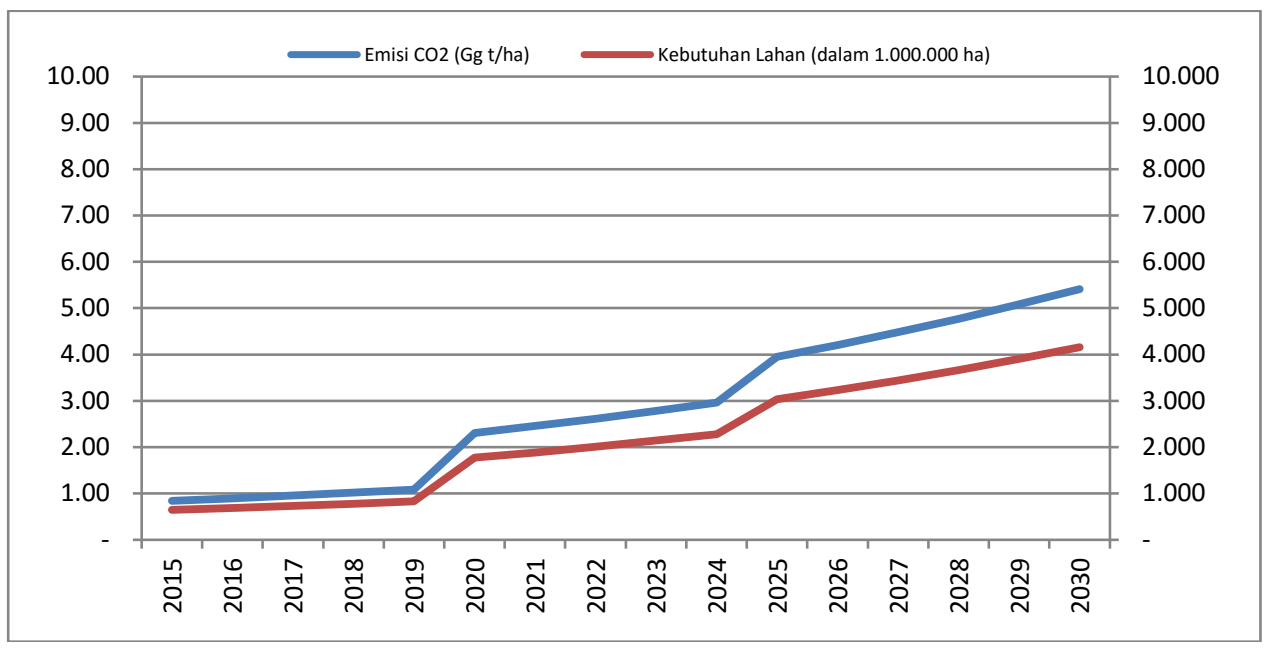

\section{Gambar 6. Proyeksi Emisi $\mathrm{CO}_{2}$ dari Penambahan Lahan Perkebunan Kelapa} Sawit

Berdasarkan hasil analisis yang telah dilakukan, telah diperolehi bahwa emisi $\mathrm{CO}_{2}$ yang dapat terjadi dari perluasan lahan perkebunan adalah berkisar antara 0,84 Gg t/ha di tahun 2015 hingga mencapai 5,41 Gg t/ha di tahun 2030.

\section{KESIMPULAN}

Penelitian ini telah berhasil merancang model matematis dalam penentuan jumlah kebutuhan bahan bakar biodiesel dalam pencampuran antara BBN dan BBM, kebutuhan luas lahan perkebunan kelapa sawit sebagai upaya pemenuhan kebutuhan bahan baku biodiesel serta tingkat emisi yang terjadi akibat praktek pembebasan lahan melalui pembakaran. Berdasarkan hasil analisis dan simulasi model matematis yang telah dibangun, dapat diperoleh beberapa kesimpulan sebagai berikut:

1. Secara umum terjadi peningkatan kebutuhan bahan bakar solar dari tahun 2015-2030 sebesar 6,5\% dengan jumlah kebutuhan total pada tahun 2030 adalah sebesar 84,56 juta KL.

2. Peningkatan kebutuhan bakar solar menyebabkan terjadinya peningkatan kebutuhan biodiesel akibat dari penerapan kebijakan pemerintah tentang pencampuran BBN dan BBM serta kebijakan penggunaan bahan bakar khusus. Adapun tingkat kebutuhan biodiesel di tahun 2030 mencapai angka 14,79 juta KL.

3. Sebagai upaya pencapaian target produksi biodiesel hingga tahun 2030, maka akan dibutuhkan luas lahan perkebunan kelapa sawit seluas 35,2 juta Ha.

4. Jika upaya pemenuhan kebutuhan lahan dilakukan melalui praktek pembakaran, akan terjadi peningkatan emisi $\mathrm{CO} 2$ total sebesar $5,41 \mathrm{Gg} \mathrm{t} \mathrm{CO}_{2}$ di tahun 2030.

Upaya pemenuhan kebutuhan energi yang terus meningkat memang harus selalu diupayakan. Pemanfaatan bahan bakar nabati merupakan salah satu alternatif yang dapat dilakukan sebagai antisipasi semakin menurunnya ketersediaan energi fosil. Namun dalam prakteknya, menjaga keseimbangan antara kebutuhan energi dan lingkungan perlu menjadi suatu perhatian tersendiri. Oleh karenanya beberapa rekomendasi yang dapat diajukan dalam hal ini antara lain:

1. Penyusunan kebijakan energi nasional khususnya pemanfaatan potensi bioenergi perlu disinergikan dengan kebijakan berkait dengan pengelolaan lingkungan. 
2. Penetapan kebijakan pemanfaatan dan pengembangan di bidang energi perlu pula memuat tentang aturan dan sanksi dari akibat pelanggaran yang mungkin terjadi yang dapat berakibat kepada kerusakan lingkungan.

3. Upaya penyediaan bahan baku bioenergi sebaiknya mempertimbangkan dampak lingkungan yang mungkin terjadi. Pemanfaatan lahan gambut secara massal memberikan dampak negatif yang sangat besar terhadap ekosistem dan oleh karenanya perlu kebijakan yang mampu menyeleksi pemanfaatan lahan yang akan diperuntukkan bagi perkebunan kelapa sawit atau jenis tanaman energi lainnya.

\section{DAFTAR PUSTAKA}

EBTKE. 2014. Statistik Energi Baru Terbarukan dan Konservasi Energi Tahun 2014.

BPS, 2013. Riau Dalam Angka Tahun 2012.

Joni, R, et al, 2011. Dampak Pengembangan Industri Biodiesel dari Kelapa Sawit terhadap Perkebunan Kelapa Sawit dan Industri Minyak Kelapa Sawit di Indonesia. Jurnal Teknologi Industri Pertanian, 20(3): 143-151.

Gamborg, C, et al. 2012. Bioenergy and Land Use: Framing the Ethical Debate, Journal Agriculture Environmental Ethics, 25:909-925

Popp, J, et al, 2014, "The Effect of Bioenergy Expansion: Food, Energy dan Environtment", Journal Renewable and Sustainable Energy Rev, 32: 559578.

Ravindran, et al. 2000. Operation Research: Principles and Practice, Wiley \& Sons. New York.

Eriyatno. 2012. Ilmu Sistem, Meningkatkan Mutu dan Efektivitas Manajemen, Jilid Satu Gunawidya Surabaya.

Lathifan, L, et al. 2014. Pemodelan Matematis untuk Analisis Kebijakan Pengembangan Industri Bahan Bakar Nabati Biodiesel dari Kemiri Sunan, Journal Teknik Industri ITENAS, 04(02): 61-72.

Handoko, H, et al. 2012. Pemodelan Sistem Dinamik Ketercapaian Kontribusi Biodiesel dalam Bauran Energi Indonesia 2025, J ManTekn, 11(1): 15-27.

Sadewo, H. 2012. Analisis Kebijakan Mandatori Pemanfaatan Biodiesel di Indonesia. [Thesis] Pascsarjana Universitas Indonesia.

Balitbang Kalimantan Tengah. 2012. Pengukuran Emisi Pada Perkebunan Kelapa Sawit Lahan Gambut. https://www.kalteng.balitbang.go.id (diakses Oktober 2015)

Renilaili dan Yuliwati, E. 2009. Rekayasa Sistem Teknologi Pembuatan Biodiesel dari CPO Menjadi Kontinyu

\section{JIEMS}

Journal of Industrial Engineering \&

Management Systems

Vol. 9, No 2, August 2016 